\title{
PIRACY AND PROBABLE ATTEMPTED PIRACY BY COMMON RAVENS ON TURKEY VULTURES
}

\author{
WILLIAM J. WALLEY, 222 Bossons Ave., Dauphin, MB, R7N 0R2
}

J.K. Terres defines kleptoparasitism or piracy as the forceful taking of food by one species of bird from another. ${ }^{3}$ In their recent treatise on the life history of the Turkey Vulture, Kirk and Mossman make reference only to Golden and Bald Eagles practicing kleptoparasitism on Turkey Vultures. ${ }^{2}$ However, A.C. Bent reports the observations of a "very trustworthy mountaineer," given to Rev. J.J. Murray, who in turn told Bent of Common Ravens "worrying" Turkey Vultures until the vultures regurgitated their food, which was then consumed by the ravens. ${ }^{1}$ In western Manitoba, there have been two observations of such raven-vulture interactions: one instance of piracy and another of probable attempted piracy.

In the summer of 2003, Hugh and Leinita Woods observed piracy by Common Ravens on Turkey Vultures (H. Woods, pers. comm.). The observation was made in Duck Mountain Provincial Park in west central Manitoba. The Woods watched in amazement as a flock of ravens induced the

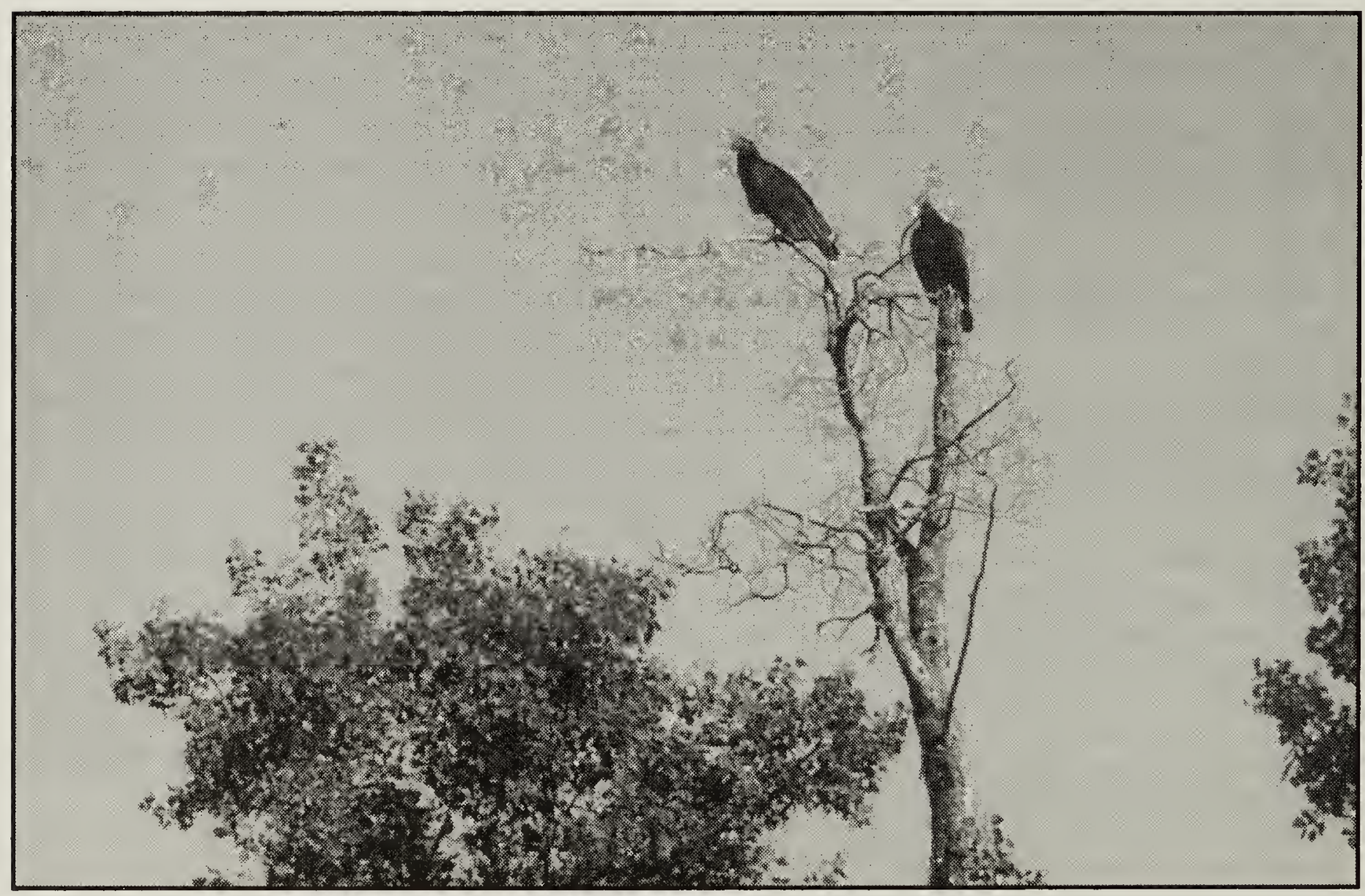

Figure 1. Two of the Turkey Vultures observed interacting with ravens on 12 July 2002.

William J. Walley. 
vultures to drop food to the ground which was subsequently consumed by the ravens.

I observed probable attempted food piracy in 2002. Mid-morning, 12 July, 2002 , was windless with a blazing hot sun one $\mathrm{km} \mathrm{E}$ of the $\mathrm{E}$ crest of the Shell Valley in Hillsburgh Municipality, some $15 \mathrm{~km} \mathrm{NE}$ of the town of Roblin. The region lies in semi-arid deeply rolling prairie dominated by sparse growth of short grasses on uplands and slopes with small but dense stands of aspen poplar (Populus tremuloides) in low areas. Around $0920 \mathrm{~h}$, two Turkey Vultures were perched in dead branches in the crown of a stunted aspen with two ravens perched just below them. As the writer approached by vehicle, the ravens flew off, but the vultures remained long enough for a photograph (Fig.1). Near $1100 \mathrm{~h}$, the movements and interactions of the ravens and vultures were observed for approximately 25 minutes from a distance of $200 \mathrm{~m}$ using a $20 \mathrm{X}$ spotting scope. Early in this time period, six Turkey Vultures arrived at the stunted aspens in ones or twos, with most small groups being followed by either one or two ravens for a total of four. Each raven perched 1.0 to 1.5 $\mathrm{m}$ below one or more of the vultures. In the building heat, all the ravens gaped, while one vulture extended its wings.

In one of the three trees occupied by the two species, a raven unhurriedly sidled upwards toward a vulture above it and extended its head toward the vulture's bill. The vulture held its perch, and, with a halfhearted thrust with its head, struck at the raven but did not make contact with it. A second raven similarly approached another vulture in another tree. In response to this advance, the vulture climbed higher, away from the raven. The raven did not continue its pursuit. Shortly thereafter, two ravens flew off and a seventh and an eighth vulture arrived. During the time the vultures and ravens occupied the trees together, and most notably just after the two ravens climbed toward the vultures, many of the birds looked downward toward the ground with great attentiveness. Eventually, the vultures flew off and spiraled upward on a thermal and the ravens dispersed.

It seems reasonable to assume that the motive for the ravens' interest in the vultures was food. How common the practice of food piracy by ravens on vultures is, and how it might have developed over time, is intriguing to speculate upon. Was it initiated at carcasses being fed upon by both scavengers? Were the vultures co-operatively feeding; that is, were a few vultures that had found food disgorging it to share with other vultures only to have the ravens intercept it, then subsequently pursue the vultures when they saw them aggregating elsewhere? Additional reports of this behaviour would enlighten naturalists as to the frequency of the practice reported years before to Rev. Murray by the "very trustworthy mountaineer."

\section{Acknowledgements}

Appreciation is extended to Hugh and Leinita Woods for the Duck Mountain observation of the raven - vulture interaction and to the editors for constructive remarks on the original manuscript.

1. BENT, A.C. 1964. Life Histories of North American Jays, Crows, and Titmice. Dover Publications, Inc., New York.

2. KIRK, D.A., and M.J. MOSSMAN. 1998. Turkey Vulture. In: The Birds of North America, No. 339 (A. Poole and F. Gill, eds). The Birds of North America, Inc., Philadelphia, PA.

3. TERRES, J.K. 1980. The Audubon Society Encyclopedia of North American Birds. Alfred A. Knopf, New York. 